\title{
Vulnerability of marine fish larvae to the toxic dinoflagellate Protogonyaulax tamarensis*
}

\author{
Serge Gosselin ${ }^{1}$, Louis Fortier ${ }^{1}$, Jacques A. Gagné ${ }^{2}$ \\ ${ }^{1}$ Département de biologie, Université Laval, Québec, Canada G1K 7P4 \\ ${ }^{2}$ Institut Maurice-Lamontagne, Ministère des Pêches et des Océans, 850 Route de la Mer, Mont-Joli, Québec, Canada G5H 3Z4
}

\begin{abstract}
Fish larvae and early postlarvae proved highly vulnerable to the toxins of the dinoflagellate Protogonyaulax tamarensis. Capelin Mallotus villosus and Atlantic herring Clupea harengus harengus larvae from the St. Lawrence Estuary, Canada, were exposed to variable concentrations of a toxic strain (treatment) and a non-toxic strain (control) of $P$. tamarensis. When exposed directly to the dinoflagellate, mortality due to the toxin (treatment minus control) was strongly correlated with the percentage of larvae that ingested cells. At cell concentrations $\left(1500\right.$ cells $\left.^{-1}\right)$ that compared with local bloom densities, mortality reached 92 and $77 \% \mathrm{~d}^{-1}$ in capelin and herring, respectively. The mortality of herring postlarvae fed toxic microzooplankton ranged from 17 to $36 \% \mathrm{~d}^{-1}$ Age- and dosedependent variations in vulnerability were linked to early ontogenetic changes in the feeding efficiency and food selectivity of both species. We conclude that the present proliferation of toxic dinoflagellates in coastal waters could jeopardize the early survival of fish and recruitment to fisheries by narrowing the spatiotemporal window within which spawning leads to successful reproduction.
\end{abstract}

\section{INTRODUCTION}

Since the 1970's, the frequency and spatial extent of toxic dinoflagellate blooms have been increasing in coastal seas of both hemispheres (White 1982a, Blanco et al. 1985, Carreto et al. 1985, Davison \& Yentsch 1985 , Krogh et al. 1985, Maclean \& White 1985, Tamiyavanich et al. 1985, White \& White 1985). Concurrent increases in the occurrence of paralytic shellfish poisoning (PSP) have been reported worldwide (Carreto et al. 1985, Dahl \& Yndestad 1985, Davison \& Yentsch 1985, Krogh at al. 1985, Tamiyavanich et al. 1985, White \& White 1985). Why catastrophic proliferations of toxic or non-toxic microalgae are becoming more frequent remains conjectural, but the general eutrophication of the coastal zone by human activity is suspected (Jingzhong et al. 1985, Prakash 1987. Sukhanova et al. 1988).

Shellfish are not the only fisheries resource potentially affected by the proliferation of toxic dinoflagellates. Fish kills related to toxic dinoflagellate blooms have been reported frequently (e.g. Adams et al. 1968 , White 1977, 1980,1981b, 1984, Avaria 1979, Jones et

\footnotetext{
- Contribution to the program of GIROQ (Groupe interuniversitaire de recherches océanographiques du Québec)
}

al. 1982, Taylor et al. 1985, Yazdandoust 1985, Potts \& Edwards 1987). The vector for finfish poisoning is herbivorous zooplankton which have been shown to accumulate the toxin (Adams et al. 1968, White 1981a, b, Boyer et al. 1985, Ives 1985. Watras et al. 1985, McClatchie 1988). Kills of adult fish are sporadic events with a limited impact on fisheries. White $(1979,1980$, $1981 \mathrm{a}, \mathrm{b}, 1982 \mathrm{~b}, 1984)$ suggested, however, that the larval and juvenile stages of fish could be vulnerable to dinoflagellate toxins. If this proved correct, the emergence of fish larvae and early postlarvae at a time when the planctonic food web is contaminated by algal toxin could lead to a significant reduction of early survival and threaten recruitment to local stocks.

So far, the issue of larval fish vulnerability to dinoflagellate toxins has received limited consideration. During the first days of life, the larvae of the majority of fish species are mixed feeders (herbivorous and carnivorous) that prey primarily on dinoflagellates, tintinnids, and invertebrate eggs (e.g. Last 1980). Thus, fish larvae can be exposed to the neurotoxin either by grazing on toxic dinoflagellates (direct intoxication) or by preying on toxic micrograzers (vectorial intoxication). Significant increases in mortality have been reported for winter flounder Pseudopleuronectes americanus, red sea bream Pagrus major, and Japan- 
ese anchovy Engraulis japonica exposed directly to mildly toxic strains of Gonyaulax excavata " (Mills \& Klein-MacPhee 1979, White et al. 1989). The potential impact of vectorial intoxication has been shown by White et al. (1989) who reported that 20 to $33 \%$ of red sea bream and Japanese anchovy larvae fed toxic zooplankton died after exhibiting typical PSP symptoms.

Given the present proliferation of toxic dinoflagellate blooms in coastal waters, the actual impact on larval fish survival of other, often more toxic species or strains, needs to be quantified. In the Estuary and northwestern Gulf of St. Lawrence, Canada, the dinoflagellate Protogonyaulax tamarensis (= Alexandrium tamarense) is responsible for some of the highest per cell toxicities ever measured (Cembella et al. 1988, Cembella \& Therriault 1989). The distribution of $P$. tamarensis is associated with the Gaspé Current (Therriault et al. 1985) which is also the dispersal area for the larvae of several species of fish, including Atlantic herring Clupea harengus harengus and capelin Mallotus villosus (Jacquaz et al. 1977, de Lafontaine et al. 1981, 1984, Fortier \& Leggett 1985).

The aim of this study was to measure experimentally the impact of Protogonyaulax tamarensis neurotoxins on the early survival of capelin and Atlantic herring. The response of the larvae to direct exposure or vectorial intoxication was established for a range of cell concentrations bracketing the densities observed during natural proliferations. Ontogenetic variations in vulnerability were determined by repeating the experiments with larvae of different ages.

\section{MATERIALS AND METHODS}

Dinoflagellate cultures. To isolate the mortality attributable exclusively to the neurotoxins from other sources of mortality, fish larvae were exposed to a nontoxic strain (control) and a toxic strain (treatment) of Protogonyaulax tamarensis. Non-toxic strain PLY173 (NEPCC183) isolated from the Tamar estuary near Plymouth, UK, was supplied by the Northeast Pacific Culture Collection (Department of Oceanography, University of British Columbia, Vancouver, Canada]. A toxic strain was developed from cells sampled in the lower St. Lawrence Estuary (isolate $\operatorname{Pr} 17 \mathrm{~b}$ of the St. Lawrence Algal Culture Collection, Department of Fisheries and Oceans, Institut Maurice-Lamontagne, Mont-Joli, Quebec, Canada). As determined by HPLC analysis, the toxin content of isolate PLY173 is null

\footnotetext{
- Some authors (Taylor 1979, Cembella et al. 1988) have assimilated Gonyaulax excavata to Protogonyaulax tamarensis
}

(Cembella et al. 1987) whereas that of isolate Pr17b reaches $10.5 \times 10^{-5} \mu \mathrm{g}$ saxitoxin equivalent cell $^{-1}$ (Cembella et al. 1988). Both cultures were grown in $\mathrm{f} / 2$ enriched filtered-seawater medium without silicate addition (Guillard 1975). Unialgal cultures were maintained under constant fluorescent light $\left(117 \mu \mathrm{Em}^{-2} \mathrm{~s}^{-1}\right)$ in salinity of $22 \%$ and temperature of $16 \pm 0.5^{\circ} \mathrm{C}$. For each experiment, cell concentration in the original suspension was determined using a Palmer-Maloney chamber $(0.1 \mathrm{ml}$ capacity). The suspension was then diluted with filtered seawater to obtain the various cell concentrations used in the experiment.

Fish larvae. Sediments containing fertilized capelin eggs were collected in the field and incubated in the laboratory following Fortier et al. (1987). Herring eggs and milt were stripped from mature spawners collected in the St. Lawrence Estuary and the fertilized eggs were incubated in the laboratory. Fish larvae were reared in flow-through containers $(20 \%$ renewal of water $\mathrm{d}^{-1}$ ) in salinities of 22 to $23 \%$ and temperatures of $8.0 \pm 1.0^{\circ} \mathrm{C}$ for capelin and $11.0 \pm 1.0^{\circ} \mathrm{C}$ for herring. Fluorescent lights (daylight type) were automatically turned on from 05:00 to 21:00 h. From hatching to the end of the experiments, the larvae of both species were fed the alga Isochrysis galbana $\left(250 \mathrm{ml}^{-1}\right)$ and the rotifer Brachionus plicatilis $\left(10 \mathrm{ml}^{-1}\right.$, adjusted daily $)$. Artemia salina nauplii (5 $\mathrm{ml}^{-1}$, adjusted daily) were added to the diet of herring lavae starting $5 \mathrm{~d}$ after hatching.

Experiments. To evaluate the effect of direct contact with Protogonyaulax tamarensis, the larvae of both fish species were exposed to the non-toxic (controls) and toxic strains (treatments) at concentrations of 250,500 , 1000 , and 1500 cells $\mathrm{ml}^{-1}$. The experiment was repeated independently with capelin larvae aged 1, 2, 3, 5, 8 and $11 \mathrm{~d}$ and herring larvae aged 1,3 and $6 \mathrm{~d}$. To evaluate the impact of the dissolved toxin, toxic and non-toxic cells were broken ultrasonically. After filtering out the cell debris, herring larvae (1, 3 and $6 \mathrm{~d}$ old $)$ were exposed to the extracted cellular content.

To evaluate the effect of vectorial intoxication, herring postlarvae 10 and $15 \mathrm{~d}$ old were fed toxic microzooplankton during independent experiments. Various proportions of toxic and non-toxic cells were offered for $12 \mathrm{~h}$ to natural assemblages of zooplankton (size range 75 to $500 \mu \mathrm{m}$ ) collected in the St. Lawrence Estuary. A concentration of 1500 cells $\mathrm{ml}^{-1}$ was maintained in each treatment by using the following ratios of toxic to non-toxic cells: 0/1500,250/1250,500/1000,1000/500, $1500 / 0$. Ungrazed dinoflagellates were sieved out after $12 \mathrm{~h}$ and the microzooplankton were offered to the postlarvae. Controls for these experiments also included starved postlarvae, postlarvae fed Isochrysis galbana, starved microzooplankton, or microzooplankton that grazed on I. galbana. 
All experiments were carried out in 3.51 fish bowls. The volume of algal culture needed to achieve the desired final cell concentration was transferred into a bowl which was then filled with seawater filtered through a $0.22 \mu \mathrm{m}$ porosity Gelman cartridge. To avoid thermal shocks, temperature in the bowls was adjusted to the rearing temperature of each fish species (capelin: $8^{\circ} \mathrm{C}$; herring: $10^{\circ} \mathrm{C}$ ) by immersion in a cooling bath. After a 30 min delay, between 30 and 100 larvae were transferred into each bowl. Gentle aeration provided an equal supply of oxygen to each container and kept the algae in suspension without stressing the larvae. For each treatment the number of dead larvae was determined $1 \mathrm{~h}$ after the transfer of the larvae and then every $4 \mathrm{~h}$. Larvae were considered dead when not responding to a gentle poke from a pipette. Dead larvae were removed after each count and frozen immediately for later determination of gut content. For each experiment, the larvae were exposed to filtered seawater and Isochrysis galbana in addition to the nontoxic Protogonyaulax tamarensis controls. These additional controls allowed evaluation of the mortality caused by experimental manipulations.

\section{RESULTS}

\section{Symptoms following ingestion of toxic Protogonyaulax tamarensis}

Gut content analysis using epifluorescence microscopy confirmed that capelin and herring larvae exposed directly to Protogonyaulax tamarensis ingested the cells. The presence of chlorophyll was easily detected but the number of cells ingested was difficult to determine because of the variable degree of digestion. Fish larvae fed equally on the toxic and nontoxic strains (Table 1). The slope (b) of the regression between the percentage of larvae feeding on the cells in the toxic treatments and the corresponding non-toxic controls (pooled data for capelin and herring: $b=$ $0.978, F=43.0, n=16, p<0.0001$ ) was not significantly different from $1(\mathrm{t}=0.145, \mathrm{p}=0.850)$. The percentage of feeding larvae increased with cell concentration for capelin (regression analysis: $F=27.1$, $\mathrm{n}=33, \mathrm{p}<0.0001)$, but not for herring $(\mathrm{F}=0.0009$, $\mathrm{n}=15, \mathrm{p}=0.976$ ).

When exposed directly to the toxic strain, both species presented symptoms of paralysis. Poisoned larvae swam erratically, sank to the bottom of the tank and were soon immobile. In general, immobile larvae did not respond to gentle poking with a pipette but some of them performed one last swimming burst. Microscopic examination of paralyzed larvae showed that the heart beat stopped within ca 20 min of complete immobilization. None of these symptoms were observed in the non-toxic controls.

\section{Direct intoxication: capelin}

Survival of capelin larvae ranged from 70 to $87 \%$ after $24 \mathrm{~h}$ of direct exposure to non-toxic Protogonyaulax tamarensis (Fig. 1) and was similar to survival in the filtered water or Isochrysis galbana controls (Table 2). Survival in the toxic treatments ranged from 0 to $72 \%$ depending on dose (i.e. toxic cell concentration) and age (Table 2). Percent survival declined linearly with time in the controls and exponentially in the toxic treatments (Fig. 1). The shape of the survival curve in larvae aged 2, 8, and $11 \mathrm{~d}$ (not shown) was similar.

Instantaneous hourly mortality rates in the non-toxic controls were estimated by fitting a linear regression of time to the percent-survival date (Fig. 1). For the toxic treatments, the instantaneous hourly mortality rate attributable to the toxin was estimated by fitting an exponential decay model that included a correction for

Table 1. Mallotus villosus and Clupea harengus harengus. Percentage of capelin and Atlantic herring larvae feeding on the toxic and non-toxic strains of Protogonyaulax tamarensis by age (days since hatching) and cell concentration. -: Not tested

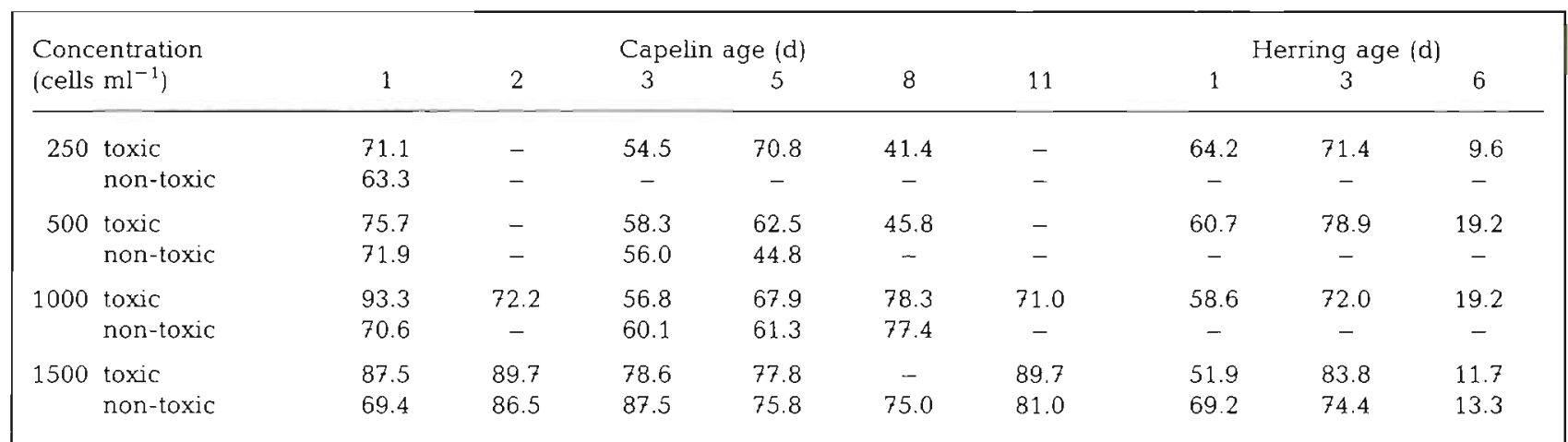




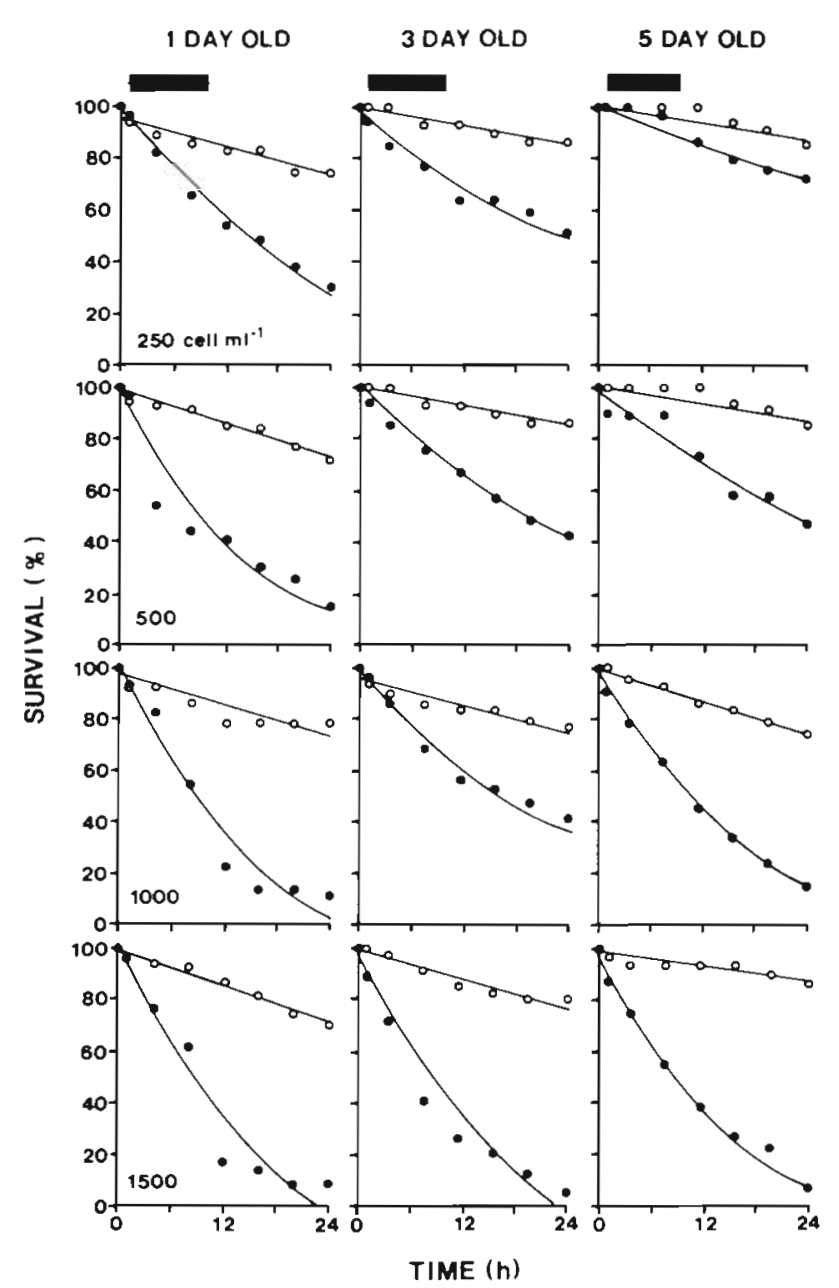

Fig. 1. Mallotus villosus. Time course of survival in capelin larvae exposed directly to a non-toxic strain (control, o) and a toxic strain (treatment, $\bullet$ ) of Protogonyaulax tamarensis at different cell concentrations and ages (days after hatching). Heavy horizontal bars represent darkness the mortality measured in the corresponding non-toxic control:

$$
S_{t}=\left(100 e^{-m t}\right)-b t
$$

where $\mathrm{S}_{\mathrm{t}}=$ percentage of larvae surviving at time $\mathrm{t}_{\mathrm{i}}$ $m=$ instantaneous hourly mortality rate attributable to the effect of the toxin (i.e. corrected for mortality in the control); and $b=$ slope of the linear regression describing survival in the corresponding non-toxic control (i.e. same or higher cell concentration of non-toxic cells). For comparison with values reported in the literature, hourly rates were transformed into daily rates:

$$
Z=1-(1-m)^{24}
$$

where $\mathrm{Z}=$ instantaneous daily mortality rate; $\mathrm{m}=$ instantaneous hourly mortality rate.

Daily mortality attributable to the effects of the toxins ranged from 17 to $92 \%$ in capelin, depending on dose and age of the larvae (Tabie 3). Mortality was proportional to toxic cell concentration (mortality $=21.5+$ 0.039 concentration, $\mathrm{F}=26.5, \mathrm{n}=19, \mathrm{p}<0.0001$ ). At low cell concentrations (250 to 500 cells $\mathrm{ml}^{-1}$ ) older larvae tended to be less susceptible than young larvae. No clear trend was visible with age at higher cell concentrations (1000 to 1500 cells $\mathrm{ml}^{-1}$ ). The daily mortality rate of capelin in the toxic treatments was strongly and linearly correlated to the percentage of larvae that ingested toxic cells (Fig. 2). For capelin of all ages, low daily mortality rates at low cell concentrations (Table 3 ) coincided with lower percentages of larvae with positive gut content (Table 1).

\section{Direct intoxication: herring}

The response of herring larvae to direct exposure to toxic cells was similar but less pronounced than the

Table 2. Mallotus villosus. Percent survival of capelin larvae after $24 \mathrm{~h}$ in controls (filtered seawater, Isochrysis galbana, non-toxic

\begin{tabular}{|c|c|c|c|c|c|c|c|}
\hline \multirow[t]{2}{*}{ Treatment } & \multirow{2}{*}{$\begin{array}{l}\text { Concentration } \\
\text { (cells } \mathrm{ml}^{-1} \text { ) }\end{array}$} & \multicolumn{6}{|c|}{ Capelin age (d) } \\
\hline & & 1 & 2 & 3 & 5 & 8 & 11 \\
\hline Filtered seawater & & 68.1 & 68.4 & 87.5 & 73.8 & 89.7 & 76.9 \\
\hline Isochrysis galbana & 1500 & 67.6 & 69.0 & 78.9 & 70.0 & 78.6 & 82.0 \\
\hline \multirow[t]{4}{*}{ Non-toxic P. tamarensis } & 250 & 74.3 & - & - & - & - & - \\
\hline & 500 & 71.9 & - & 86.2 & 85.7 & - & - \\
\hline & 1000 & 78.4 & 69.8 & 77.1 & 74.4 & 78.6 & - \\
\hline & 1500 & 70.4 & - & 80.0 & 86.7 & 75.6 & 77.8 \\
\hline \multirow[t]{4}{*}{ Toxic P. tamarensis } & 250 & 30.0 & - & 51.3 & 72.4 & 61.0 & - \\
\hline & 500 & 15.2 & - & 42.9 & 47.4 & 51.6 & - \\
\hline & 1000 & 11.3 & 32.3 & 41.2 & 15.1 & 15.4 & 27.7 \\
\hline & 1500 & 8.7 & 15.8 & 5.1 & 7.5 & - & 0.1 \\
\hline
\end{tabular}
Protogonyaulax tamarensis) and experimental treatments (toxic P. tamarensis). -: Not tested 
Table 3. Mallotus villosus. Instantaneous daily mortality $\left(\% \mathrm{~d}^{-1}\right.$, Eqs. [1] and [2]) at age (days since hatching) in capelin larvae exposed directly to the toxic dinoflagellate Protogonyaulax tamarensis at different cell concentrations. Estimates are corrected for the mortality observed in the non-toxic controls and represent the mortality imputable exclusively to the effects of the toxin. Initial number of larvae in the experimental treatment given in parentheses; $\%$ yolk sac: percentage of larvae with yolk sac; -; not tested

\begin{tabular}{|c|c|c|c|c|c|c|}
\hline $\begin{array}{l}\text { Concentration } \\
\text { (cells } \mathrm{ml}^{-1} \text { ) }\end{array}$ & 1 & 2 & 3 & 5 & 8 & 11 \\
\hline 250 & $52.3(50)$ & - & $32.8(39)$ & $17.1(39)$ & $16.9(41)$ & - \\
\hline 500 & $66.3(59)$ & - & $42.2(49)$ & $37.7(39)$ & $25.5(31)$ & - \\
\hline 1000 & $83.9(62)$ & $37.4(62)$ & $43.8(51)$ & $63.8(33)$ & $82.5(33)$ & $52.3(47)$ \\
\hline 1500 & $78.3(46)$ & $64.1(57)$ & $81.3(39)$ & $83.1(40)$ & - & $92.1(40)$ \\
\hline$\%$ yolksac & 100.0 & 100.0 & 87.5 & 7.7 & 0 & 0 \\
\hline
\end{tabular}

response of capelin (Fig. 3). Survival in the non-toxic control (1500 cells $\mathrm{ml}^{-1}$ ) was high and similar to survival in other controls (Table 4 ). In the toxic treatments, survival after $24 \mathrm{~h}$ was usually higher than in capelin of the same age. In herring aged 1, 3 and $6 \mathrm{~d}$, the survival curve presented an initial period of latency, mortality starting only after the lights were turned on in the morning (Fig. 3).

To estimate instantaneous mortality rates, Eq. (1) was adjusted to the percent survival data starting with the first data point taken after the lights were turned on. Herring mortality following direct exposure to toxic cells decreased with age (Table 5), and was only marginally correlated to cell concentration (mortality $=10.76$ +0.024 concentration, $\mathrm{F}=4.19, \mathrm{n}=12, \mathrm{p}=0.068$ ). Lower mortality rates at age $6 \mathrm{~d}$ (Table 5) coincided with a lower percentage of larvae with cells in their gut (Table 1). When one outlier point was excluded from the regression, daily mortality rate in the toxic treatments was significantly correlated to the percentage of larvae with toxic cells in their gut (Fig 4). Herring larvae of different ages showed little response to the dissolved toxins or membranes of broken cells (Table 4).

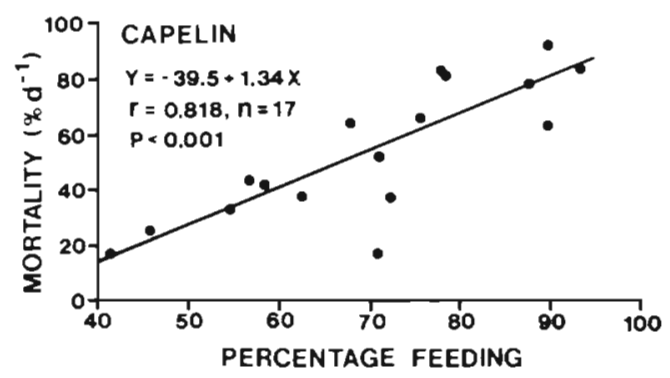

Fig. 2. Mallotus villosus. Instantaneous daily mortality rate (Eqs. 1 and 2) of capelin larvae attributable to the neurotoxins, as a function of the percentage of larvae that ingested toxic

Protogonyaulax tamarensis cells during the experiment

\section{Vectorial intoxication}

The survival of herring postlarvae in the different non-toxic controls of these experiments ranged from 65 to $95 \%$ after $36 \mathrm{~h}$ (Fig. 5). Survival in the presence of microzooplankton that were fed toxic Protogonyaulax

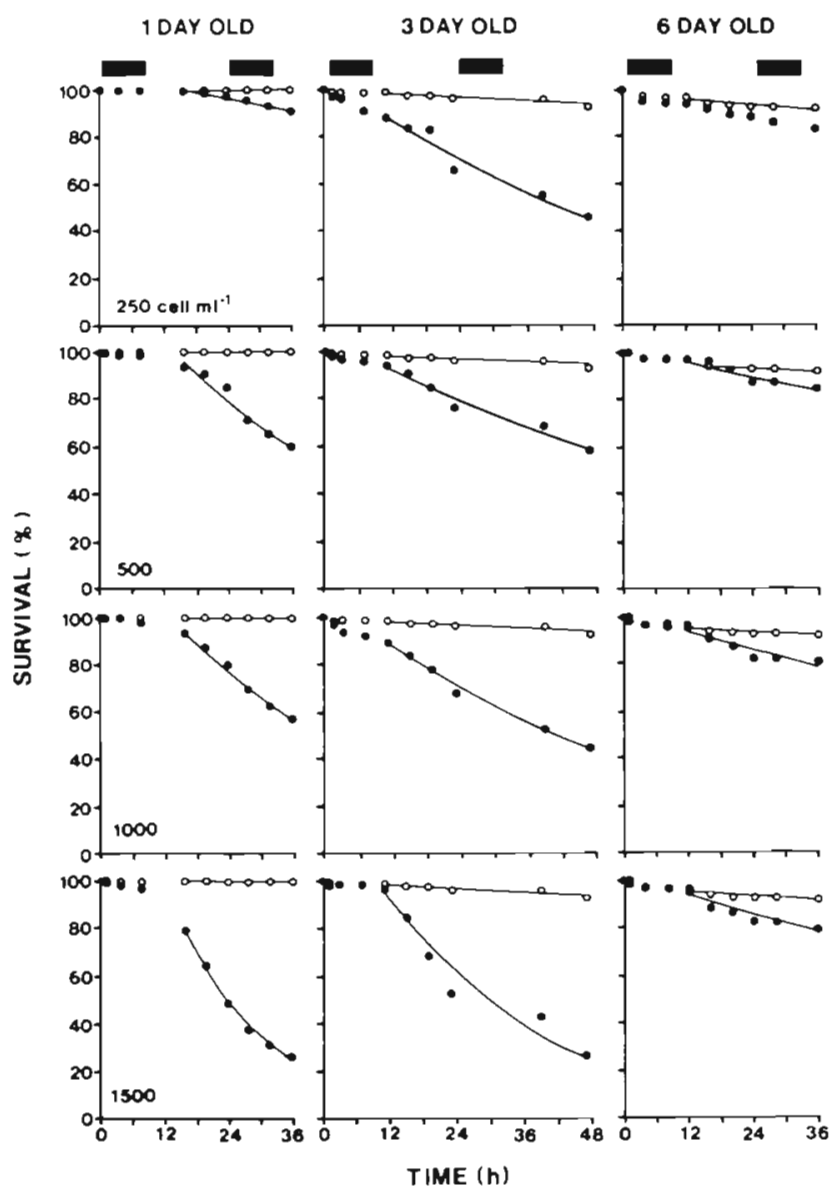

Fig. 3. Clupea harengus harengus. Time course of survival in Atlantic herring larvae exposed directly to a non-toxic strain (control, 0 ) and a toxic strain (treatment, $\bullet$ ) of Protogonyaulax tamarensis at different cell concentrations and ages (days after hatching). Heavy horizontal bars represent darkness 
Table 4. Clupea harengus harengus. Percent survival after $36 \mathrm{~h}$ for herring larvae in controls (filtered seawater, Isochrysis galbana, non-toxic Protogonyaulax tamarensis) and experimental treatments (toxic $P$. tamarensis, average of triplicates)

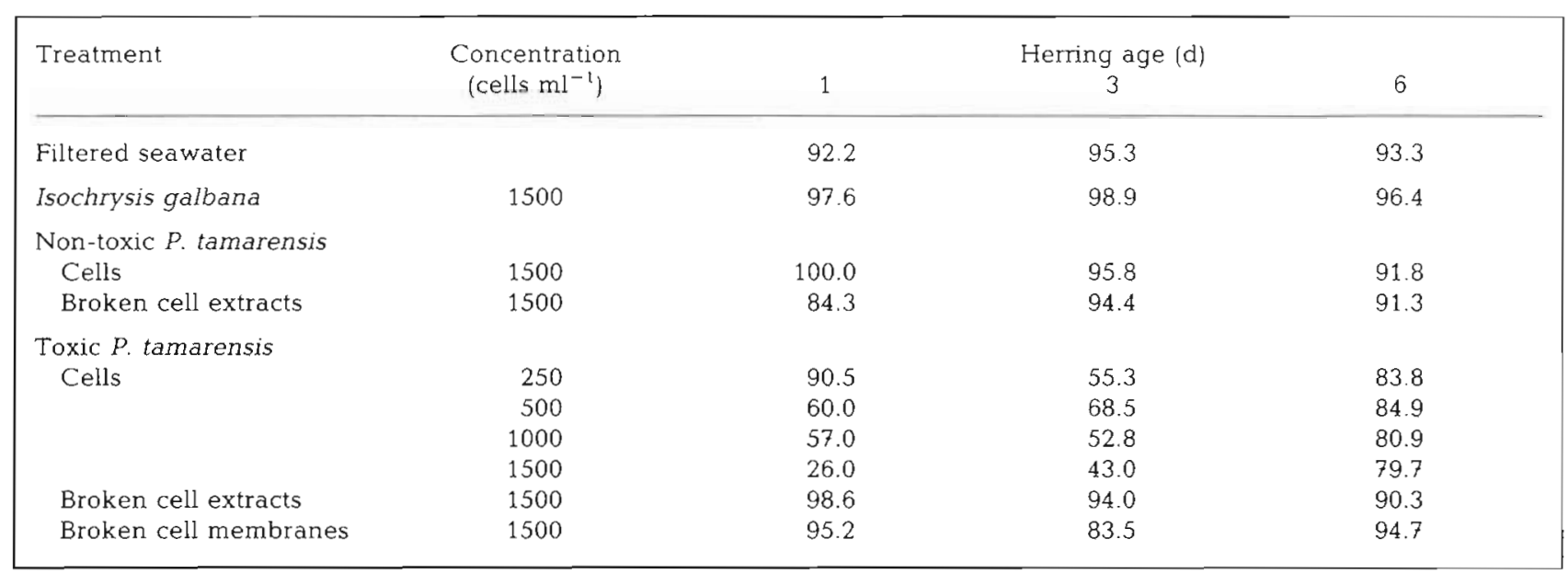

Table 5. Clupea harengus harengus. Instantaneous daily mortality $\left(\% \mathrm{~d}^{-1}\right)$ of Atlantic herring larvae exposed directly to different concentrations of the toxic dinoflagellate Protogonyaulax tamarensis (age 1, 3, and $6 \mathrm{~d}$ ), or to toxic microzooplankton that fed for $12 \mathrm{~h}$ on different concentrations of $P$. tamarensis (age 10 and $15 \mathrm{~d}$ ) (see text). Estimates are corrected for the mortality observed in non-toxic controls and represent the mortality imputable exclusively to the effects of the toxin. Initial number of larvae in the experimental treatment given in parentheses; \% yolk sac: percentage of larvae with yolk sac

\begin{tabular}{|lccccc|}
\hline $\begin{array}{c}\text { Concentration } \\
\text { (cells ml }{ }^{-1} \text { ) }\end{array}$ & 1 & $\begin{array}{c}\text { Age (d) } \\
3\end{array}$ & 6 & Age (d) \\
(direct exposure) & & (vectorial exposure) \\
\hline 250 & $10.8(69)$ & $23.2(80)$ & $6.7(66)$ & $17.5(64)$ & $33.6(45)$ \\
500 & $43.6(73)$ & $31.8(79)$ & $9.6(77)$ & $29.2(66)$ & $29.1(50)$ \\
1000 & $46.1(76)$ & $33.1(91)$ & $12.2(67)$ & $26.8(66)$ & $33.3(50)$ \\
1500 & $76.6(63)$ & $53.4(82)$ & $11.8(71)$ & $19.5(72)$ & $36.3(60)$ \\
$\%$ yolk sac & 100.0 & 62.8 & 11.5 & 0 & 0 \\
\end{tabular}

tamarensis ranged from 23 to $43 \%$ The survival curves were remarkably similar in the 4 toxic treatments. Final survival was independent of the proportion of toxic dinoflagellates in the food of the microzooplankton. These experiments were started at 18:00 $\mathrm{h}$ when the light was still on. A few herring postlarvae aged $10 \mathrm{~d}$ died before the light was turned off, but the percentage

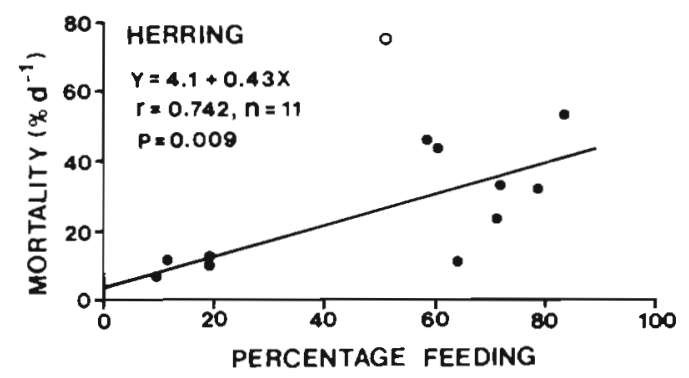

Fig. 4. Clupea harengus harengus. Instantaneous daily mortality rate of Atlantic herring larvae attributable to the neurotoxins, as a function of the percentage of larvae that ingested toxic Protogonyaulax tamarensis cells during the experment. Open symbol omitted from the regression of survivors began to decline linearly only when the light was turned on again in the morning (Fig. 5). In herring postlarvae aged $15 \mathrm{~d}$, the linear decline in the percentage of survivors started immediately after the beginning of the experiment.

Instantaneous mortality rates attributable to the toxin were estimated by fitting a linear regression of time to the linear portion of the survival curves. The regression included a correction for the mortality measured in postlarvae fed microzooplankton that grazed on nontoxic cells. Daily mortality rates attributable to the toxin ranged from 18 to $36 \% \mathrm{~d}^{-1}$ (Table 5). Mortality rates were unrelated to the proportion of toxic dinoflagellates in the food of the microzooplankton (pooled data for ages 10 and $15 \mathrm{~d}, \mathrm{r}=0.111, \mathrm{p}=0.794, \mathrm{n}=8$ ).

\section{DISCUSSION}

\section{Larval fish vulnerability to dinoflagellate toxins}

Exposure to Protogonyaulax tamarensis caused heavy mortality in marine fish larvae and early postlar- 

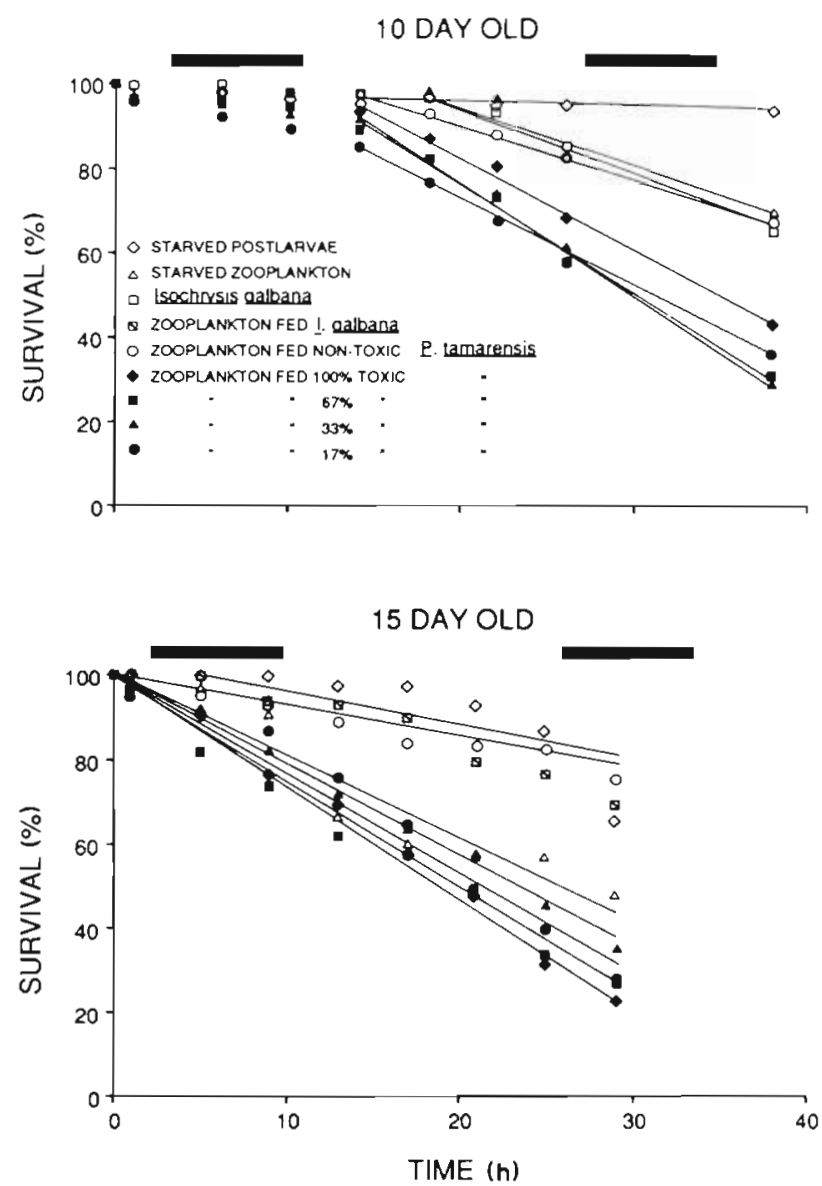

Fig. 5. Clupea harengus harengus. Time course of survival in Atlantic herring postlarvae fed microzooplankton (75 to $500 \mu \mathrm{m}$ ) that had been grazing for $12 \mathrm{~h}$ on various mixtures of toxic and non-toxic Protogonyaulax tamarensis (see 'Materials and methods'). Controls include starved postlarvae, postlarvae fed Isochrysis galbana, starved microzooplankton, or microzooplankton that grazed on I. galbana. Heavy horizontal bars represent darkness

vae, through either direct or vectorial intoxication. The range of cell concentrations used in the experiments (250 to 1500 cells $\mathrm{ml}^{-1}$ ) compared with natural densities of $P$. tamarensis in the St. Lawrence Estuary, which average 300 cells $\mathrm{ml}^{-1}$ during significant proliferations with peak concentrations of 5000 cells $\mathrm{ml}^{-1}$ in surface waters (Therriault et al. 1985)

In studies of the impact of Gonyaulax excavata on the early survival of fish, the symptoms of paralysis observed in larvae left little doubt that part of the mortality was due to the neurotoxin (Mills \& KleinMacPhee 1979, White et al. 1989). However, the actual impact of the toxin proved difficult to isolate from nontoxic effects. For example, Japanese anchovy larvae fed poorly on $G$. excavata, and mortality in the toxic treatments was attributed to starvation rather than poisoning (White et al. 1989). In the present study, the mortality attributable exclusively to the toxin of Pro- togonyaulax tamarensis was isolated from other sources of mortality by using a non-toxic strain as control.

In yolk sac larvae, daily mortality due exclusively to the toxin ranged from 33 to $84 \% \mathrm{~d}^{-1}$ for capelin and from 11 to $77 \% \mathrm{~d}^{-1}$ for herring, depending on age and dose (i.e. toxic cell concentration). In postlarvae, mortality ranged from 17 to $92 \% \mathrm{~d}^{-1}$ for capelin and from 18 to $36 \% \mathrm{~d}^{-1}$ for herring. In a review by Dahlberg (1979), mortalities reported from field studies ranged from 4 to $47 \% \mathrm{~d}^{-1}$ (average of $21.2 \% \mathrm{~d}^{-1}, \mathrm{n}=16$ ) in yolk sac larvae and from 3 to $15 \% \mathrm{~d}^{-1}$ (average $7.7 \%$ $\mathrm{d}^{-1}, \mathrm{n}=13$ ) in postlarvae. Thus the additional mortality caused in the laboratory by the toxicity of natural concentrations of Protogonyaulax tamarensis is at least of the same magnitude and often much higher than the average mortality experienced by fish larvae in nature

Our results confirm the findings of previous experimental studies of the impact of Gonyaulax excavata on the early survival of fish. On a cell-to-cell basis however, Protogonyaulax tamarensis proved a much more potent agent of mortality than $G$. excavata. Winter flounder Pseudopleuronectes americanus larvae exposed directly to toxic $G$. excavata at concentrations of 100 to 250 cells $\mathrm{ml}^{-1}$ showed some increase in mortality after several days of exposure (Mills \& Klein-MacPhee 1979). First-feeding red sea bream Pagrus major larvae exposed to a mildly toxic strain of the same dinoflagellate at concentrations of 300 cells $\mathrm{ml}^{-1}$ exhibited a 3 fold increase in mortality after 4 to $7 \mathrm{~d}$ (White et al. 1989). In the present study, the impact of $P$. tamarensis toxins on the larvae became evident within hours of exposure rather than days, even at the lowest concentration of toxic cells (250 cells $\mathrm{ml}^{-1}$ ). At the highest concentrations (1000 and 1500 cells $\mathrm{ml}^{-1}$ ), the experimental populations were often nearly annihilated in less than $24 \mathrm{~h}$

Natural strains of Protogonyaulax tamarensis from the Estuary and Gulf of the St. Lawrence are extremely toxic, as is often the case at high latitudes (Maranda et al. 1985). The toxicity of 9 natural populations sampled in the St. Lawrence Estuary ranged from 3 to $13 \times 10^{-5}$ $\mu \mathrm{g}$ saxitoxin (STX) equivalent cell ${ }^{-1}$ (Cembella et al 1988). The toxin content per cell of isolate $\operatorname{Pr} 17 \mathrm{~b}$ used in the present study was estimated at $10.5 \times 10^{-5} \mu \mathrm{g}$ STX equivalent cell ${ }^{-1}$ (Cembella et al. 1988), whereas the toxin content of the strain of Gonyaulax excavata used by White et al. (1989) was $2 \times 10^{-5} \mu \mathrm{g}$ STX equivalent cell ${ }^{-1}$. Assuming that the oral LD $_{50}$ was similar for adult and larval fish, White et al. (1989) calculated that first-feeding fish larvae (ca $0.28 \mathrm{mg}$ wet wt) needed to ingest 6 to $11 \mathrm{G}$. excavata cells to acquire a lethal dose. Similar calculations indicate that firstfeeding capelin (ca $0.13 \mathrm{mg}$ wet weight) and herring (ca $0.17 \mathrm{mg}$ wet weight) larvae would acquire a lethal dose after ingesting from 0.6 to 0.9 and 0.7 to 1.2 cells of 
isolate $\operatorname{Pr} 17 \mathrm{~b}$ respectively. Thus, a single cell of the most toxic strains sampled in the St. Lawrence Estuary contains enough toxin to kill a first-feeding fish larva. This higher toxicity of $P$. tamarensis relative to $G$. excavata would account for the much quicker and heavier impact on the early survival of fish measured in the present study.

\section{Feeding ecology and ontogenetic trends in vulnerability}

Mortality in both species was correlated to the percentage of larvae that fed on the toxic cells. Capelin of all ages fed on the cells, but feeding was limited at low densities of dinoflagellates. Consequently, vulnerability to direct exposure was proportional to the concentration of toxic cells and did not vary much with age. The percentage of herring larvae ingesting dinoflagellate cells was independent of cell density but decreased sharply at the resorption of the yolk sac. Hence, herring vulnerability to direct exposure was only weakly correlated to the concentration of toxic cells and declined at the onset of the postlarval stage. These ontogenetic trends in vulnerability are consistent with the early feeding behavior of each species in nature. Soon after hatching, both capelin (Moksness 1982) and herring (Marshall et al. 1937, Bhattacharyya 1957, Blaxter 1965) feed on phytoplankton. At yolk sac resorption, both species become primarily carnivorous but capelin remains a mixed feeder for several weeks (Moksness 1982) while it is uncommon to find plant material in the gut of postlarval herring (Marshall et al. 1937. Bhattacharyya 1957, Blaxter 1965). In some instances, response to the toxin was related to light intensity in herring but not in capelin. This suggested that herring larvae could not feed on the cells or on toxic zooplankton in the dark.

By becoming primarily carnivorous after yolk sac resorption, herring postlarvae reduced their susceptibility to direct intoxication but remained susceptible to vectorial poisoning. Herring postlarvae developed typical paralysis symptoms when fed microzooplankton. that had been grazing for $12 \mathrm{~h}$ on toxic Protogonyaulax tamarensis, in agreement with the response of Japanese anchovy and red sea bream postlarvae fed toxic zooplankton (White et al. 1989). Interestingly, herring mortality through vectorial intoxication was independent of the proportion of toxic cells in the mixture of toxic and non-toxic cells given to the microzooplankton. This suggests that after $12 \mathrm{~h}$ of grazing, microzooplankton tissues became saturated with the toxin even at the lowest proportion of toxic cells (250/1500 cells)

\section{Potential for intoxication of fish larvae in nature}

By isolating toxic Gonyaulax excavata in a cage, White et al. (1989) showed that fish larvae are insensitive to potentially toxic products excreted by the cells. Our own experiments with dissolved toxin confirmed that the toxin is assimilated only when the toxic cells are ingested. It follows that mortality should be proportional to the percentage of larvae feeding on the cells, a prediction confirmed by the linear relationship found between daily mortality rate and the percentage of larvae with toxic cells in their gut.

These observations imply that, in nature, the effect of the toxin on larval fish survival could be dampened by gustatory rejection of toxic cells or toxic prey. Yamamori et al. (1988) demonstrated that saxitoxin (one of the several neurotoxins produced by the genus Gonyaulax) is a highly effective gustatory stimulus in adult fish, and suggested the existence of a specific mechanism for the rejection of toxic prey. Yet, our results indicated no such gustatory rejection by the larval stages of both species which fed equally on the toxic and non-toxic strains of Protogonyaulax tamarensis.

In nature, the availability of alternate preferred prey could reduce the probability that fish larvae ingest toxic dinoflagellate cells or toxic zooplankton. A priori, this could be particularly important during the early phytophagous yolk sac stage since other large phytoplankton cells such as diatoms cannot serve as vector of the toxins. In his extensive review of the food of marine fish larvae, Last (1980) reported that 15 out of 20 species fed on dinoflagellates whereas only 6 ingested diatoms. Dinoflagellates represented up to $55 \%$ (average $18.7 \%$ of the diet of the earlier stages whereas that percentage did not exceed $5 \%$ (average $2.0 \%$ ) for diatoms, a situation perhaps related to the motility of dinoflagellates and their consequent greater visibility to fish larvae. Given this apparent preference for dinoflagellates, the probability will remain low that during any significant proliferation of toxic dinoflagellates a yolk sac larva avoids ingesting the one or few toxic cells needed to be fatal, irrespective of the abundance of other large non-toxic phytoplankton cells.

For the carnivorous postlarvae, alternate non-toxic prey will be available only in the unlikely situation where the contamination of the trophic web by dinoflagellate toxins is restricted to one or a few herbivorous zooplankton species. Even then, fish postlarvae would need to select exclusively the non-toxic species to survive. Both field measurements (White 1980) and laboratory experiments (White 1981a) show that most taxa of herbivorous zooplankton become toxic during blooms of Gonyaulax excavata. We conclude that fish larvae and early postlarvae are unlikely to escape in- 
toxication in the event of a significant proliferation of toxic dinoflagellates.

Therefore, a spatiotemporal coincidence in nature between the emergence of fish larvae and the proliferation of toxic dinoflagellates could lead to massive mortalities. We propose that for areas where toxic dinoflagellates have been a regular component of the phytoplankton community over an evolutionary time-scale, recurring kills of young stages from intoxication have constituted an additional selective constraint in determining fish spawning strategies. Spawning strategies evolved in response to the long-term historical distributions of the toxicity could not prevent the emergence of the larvae into areas or seasons newly colonized by toxic dinoflagellates. Thus the present extensions of the spatial and seasonal distribution of toxic dinoflagellates (see several studies in Anderson et al. 1985) could significantly impair recruitment to finfish stocks by reducing the spatiotemporal window within which successful reproduction is possible.

Acknowledgements. The Natural Sciences and Engineering Research Council of Canada (NSERC) and le Conseil des Recherches en Pêche et Agroalimentaire du Québec (CORPAQ) provided financial support. This work was supported by GIROQ thanks to NSERC and the Fonds pour la formation de Chercheurs et l'aide à la recherche (FCAR). Special thanks to Rene Drolet for help in the laboratory and to A. Cembella, B. Robineau and A. Cardinal for enlightening discussions of experimental designs and results.

\section{IITERATURE CITED}

Adams, J. A., Seaton, D. D., Buchanan, J. B., Longbottom, M R. (1968). Biological observations associated with the toxic phytoplankton bloom off the east coast. Nature, Lond. 220 $24-25$

Anderson, D. M., White, A. W., Baden, D. G. (eds.) (1985) Toxic dinoflagellates. Elsevier, New York

Avaria, S. P. (1979). Red tides off the coast of Chile. In: Taylor, D. L, Seliger, H. H. (eds.) Toxic dinoflagellate blooms Elsevier, New York, p. 161-164

Bhattacharyya, R. N. (1957). The food and feeding habits of larval and post-larval herring in the northern North Sea. Mar. Res. Scot. 3: 1-14

Blanco, J., Mariño, J., Campos, M. J. (1985). The first toxic bloom of Gonyaulax tamarensis detected in Spain (1984). In: Anderson, D. M., White, A. W., Baden, D. G. (eds.) Toxic dinoflagellates. Elsevier, New York, p. 79-84

Blaxter, J. H. S. (1965). The feeding of herring larvae and their ecology in relation to feeding. Calif. coop. oceanic Fish. Invest. Rep. 10: 79-88

Boyer, G. L., Sullivan, J. J., LeBlanc, M., Andersen, R. J. (1985). The assimilation of PSP toxins by the copepod Tigriopus californicus from dietary Protogonyaulax catanella. In: Anderson, D. M., White, A. W., Baden, D. G. (eds.) Toxic dinoflagellates. Elsevier, New York, p. $407-412$

Carreto, J. I., Negri, R. M., Benavides, H. R., Akselman, R (1985). Toxic dinoflagellate blooms in the Argentine sea
In: Anderson, D. M., White, A. W., Baden, D. G. (eds.) Toxic dinoflagellates. Elsevier, New York, p. 147-152

Cembella, A. D., Sullivan, J. J., Boyer, G. L., Taylor, F. J. R., Andersen, R. J. (1987). Variation in paralytic shellfish toxin composition within the Protogonyaulax tamarensisf catanella species complex; red tide dinoflagellates. Biochem. Syst. Ecol. 15: 171-186

Cembella, A. D., Therriault, J.-C. (1989). Population dynamics and toxin composition of Protogonyaulax tamarensis from the St. Lawrence estuary. In: Okaichi, T., Anderson, D. M., Nemoto, T (eds.) Red tides: biology, environmental science and toxicology. Elsevier, New York, p. 81-84

Cembella, A. D., Therriault, J.-C., Béland, P. (1988). Toxicity of cultured isolates and natural populations of Protogonyaulax tamarensis from the St. Lawrence estuary. J. Shellfish Res. 7: 611-621

Dahl, E., Yndestad, M. (1985). Diarrhetic shellfish poisoning (DSP) in Norway in the autumn 1984 related to the occurrence of Dinophysis spp. In: Anderson, D. M., White, A. W. Baden, D. G. (eds.) Toxic dinoflagellates. Elsevier, New York, p. 495-500

Dahlberg, M. D. (1979). A review of survival rates of fish eggs and larvae in relation to impact assessments. Mar. Fish. Rev. 41: 1-12

Davison, P., Yentsch, C. M. (1985). Occurrence of toxic dinoflagellates and shellfish toxin along coastal Uruguay, South America. In: Anderson, D. M., White, A. W., Baden, D. G., (eds.) Toxic dinoflagellates. Elsevier, New York, p. $153-158$

de Lafontaine, Y., El-Sabh, M. I., Sinclair, M., Messieh, S. N., Lambert, J.-D. (1984). Structure océanographique et distribution spatiotemporelle d'oeufs et de larves de poissons dans l'estuaire maritime et la partie ouest du golfe SaintLaurent. Sci. Tech. Eau 17: 43-50

de Lafontaine, Y., Sinclair, M., Messieh, S. N., El-Sabh, M. I., Lassus, C. (1981). Ichthyoplankton distributions in the northwestern Gulf of St. Lawrence. Rapp. P.-v. Réun. Cons. int. Explor. Mer 178: 185-187

Fortier, L., Leggett, W. C. (1985). A drift study of larval fish survival. Mar. Ecol. Prog. Ser. 25: 245-257

Fortier, L., Leggett, W. C., Gosselin, S. (1987). Patterns of larval emergence and their potential impact on stock differentiation in beach spawning capelin (Mallotus villosus). Can. J. Fish. Aquat. Sci. 44: 1326-1336

Guillard, R. R. L. (1975). Culture of phytoplankton for feeding marine invertebrates. In: Smith, $W$ L., Chanley, $M$. H. (eds.) Culture of marine invertebrate animals. Plenum, New York, p. 29-60

Ives, J. D. (1985). The relationship between Gonyaulax tamarensis cell toxin levels and copepod ingestion rates. In: Anderson, D. M., White, A. W., Baden, D. G. (eds.) Toxic dinoflagellates. Elsevier, New York, p. 413-418

Jacquaz, B., Able, K. W., Leggett, W. C. (1977). Seasonal distribution, abundance, and growth of larval capelin (Mallotus villosus) in the St. Lawrence estuary and northwestern Gulf of St. Lawrence. J. Fish. Res. Bd Can. 34: 2015-2029

Jirızhong, Z., Liping, D., Baoping, Q. (1985). Preliminary studies on eutrophication and red tide problems in Bohai Bay. Hydrobiologia 127: 27-30

Jones, K. J., Ayres, P., Bullock, A. M., Roberts, R. J., Tett, P. (1982). A red tide of Gyrodinium aureolum in sea lochs of the Firth of Clyde and associated mortality of pond-reared salmon. J. mar. biol. Ass. U.K. 62: 771-782

Krogh, P., Edler, L., Graneli, E., Nyman, U. (1985). Outbreak of diarrheic shellfish poisoning on the west coast of Sweden. In: Anderson, D. M., White, A. W., Baden, D. G. 
(eds.) Toxic dinoflagellates. Elsevier, New York, p. 501-503

Last, J. M. (1980). The food of twenty species of fish larvae in the west-central North Sea. Fish. Res. Tech. Rep. MAFF Direct. Fish. Res., Lowestoft 60: 1-44

MacLean, J. L., White, A. W (1985). Toxic dinoflagellate blooms in Asia: a growing concern. In: Anderson, D. M., White, A. W. Baden, D. G. (eds.) Toxic dinoflagellates. Elsevier, New York, p. 517-520

Maranda, L., Anderson, D. M., Shimizu, Y (1985). Comparison of toxicity between populations of Gonyaulax tamarensis of eastern North American waters. Estuar. coast. Shelf Sci. 21: 401-410

Marshall, S. M. Nicholls, A. G., Orr, A. P. (1937). On the growth and feeding of the larval and postlarval stages of the Clyde herring. J. mar. biol. Ass. U.K. 22: 245-267

McClatchie, S. (1988). Functional response of the euphausid Thysanoessa raschii grazing on small diatoms and toxic dinoflagellates. J. mar. Res. 46: 631-646

Mills, L. J., Klein-MacPhee, G. K. (1979). Toxicity of the New England red tide dinoflagellate to winter flounder larvae. In: Taylor, D. L., Seliger, H. H. (eds.) Toxic dinoflagellate blooms. Elsevier, New York, p. 389-394

Moksness, E. (1982). Food uptake, growth and survival of capelin larvae (Mallotus villosus Müller) in an outdoor constructed basin. FiskDir. Skr. (Ser Havunders.) 17: $267-285$

Potts, G. W., Edwards, J. M. (1987). The impact of a Gyrodinium aureolum bloom on inshore young fish populations. J. mar. biol. Ass. U.K, 67: 293-297

Prakash, A. (1987). Coastal organic pollution as a contributing factor to red-tide development. Rapp. P.-v. Réun. Cons. int. Explor. Mer 187. 61-65

Sukhanova, I. N., Flint, M. V., Hibaum, G., Karamfilov, V. Kopylov, A. I., Matveeva, E., Rat'kova, T N., Sazhin, A. F (1988). Exuviaella cordata red tide in Bulgarian coastal waters (May to June 1986). Mar. Biol. 99: 1-8

Tamiyavanich, S., Kodama, M., Fukuyo, X (1985). The occurrence of paralytic shellfish poisoning in Thailand. In: Anderson, D. M., White, A. W., Baden, D. G. (eds.) Toxic dinoflagellates. Elsevier, New York, p. 521-524

Taylor, F. J. R. (1979). The toxicogenic gonyaulacoid dinoflagellates. In: Taylor, D. L., Seliger, H. H. (eds.) Toxic dinoflagellate blooms. Elsevier, New York, p. 47-56

Taylor, F. J. R., Taylor, N. J., Walsby, J. R. (1985). A bloom of the planktonic diatom, Cerataulina pelagica, off the coast of northeastern New Zealand in 1983, and its contribution to an associated mortality of fish and benthic fauna. Int. Revue ges. Hydrobiol. 70: 773-795

Therriault, J. C., Painchaud, J., Levasseur, M. (1985). Factors controlling the occurrence of Protogonyaulax tamarensis and shellfish toxicity in the St. Lawrence Estuary: fresh-

This article was presented by Professor P. J. Wangersky, Halifax, Nova Scotia, Canada water runoff and the stability of the water column. In: Anderson, D. M., White, A. W., Baden, D. G. (eds.) Toxic dinoflagellates. Elsevier, New York, p. 141-146

Watras, C. J., Garcon, V C., Olson, R. J., Chilshom, S. W., Anderson, D. M. (1985). The effect of zooplankton grazing on estuarine blooms of the toxic dinoflagellate Gonyaulax tamarensis. J. Plankton Res. 6: 891-908

White, A. W. (1977). Dinoflagellate toxins as probable cause of an Atlantic herring (Clupea harengus harengus) kill, and pteropods as apparent vector. J. Fish. Res. Bd Can. 34: $2421-2424$

White, A. W. (1979). Dinoflagellate toxins in phytoplankton and zooplankton fractions during a bloom of Gonyaulax excavata. In: Taylor, D. L., Seliger, H. H. (eds.) Toxic dinoflagellate blooms. Elsevier, New York, p. 381-384

White, A. W. (1980). Recurrence of kills of Atlantic herring (Clupea harengus harengus) caused by dinoflagellate toxins transferred through herbivorous zooplankton. Can. J. Fish. Aquat. Sci. 37: 2262-2265

White, A. W. (1981a). Marine zooplankton can accumulate and retain dinoflagellate toxins and cause fish kills. Limnol. Oceanogr. 26: 103-109

White, A. W (1981b). Sensitivity of marine fishes to toxins from the red-tide dinoflagellate Gonyaulax excavata and implications for fish kills. Mar. Biol. 65: 255-260

White, A. W. (1982a). Intensification of Gonyaulax blooms and shellfish toxicity in the Bay of Fundy. Can. Tech. Rep. Fish. Aquat. Sci. 1064: 1-12

White, A. W. (1982b). The scope of impact of toxic dinoflagellate blooms on finfish in Canada. Can. Tech. Rep. Fish. Aquat. Sci. 1063: 1-5

White, A. W. (1984). Paralytic shellfish toxins and finfish. In Ragelis, E. P. (ed.) Seafood toxins. ACS symposium series 262. Amer. Chem. Soc., Washington, D.C., p. 171-180

White, A. W. Fukuhara, O., Anraku, M. (1989). Mortality of fish larvae from eating toxic dinoflagellates or zooplankton containing dinoflagellate toxins. In: Okaichi, $T$. Anderson, D. M., Nemoto, T. (eds.) Red tides: biology, environmental science and toxicology. Elsevier, New York, p. 395-398

White, D. R. L. White, A. W. (1985). First report of paralytic shellfish poisoning in Newfoundland. In: Anderson, D. M., White, A. W., Baden, D. G. (eds.) Toxic dinoflagellates. Elsevier, New York, p. 511-516

Yamamori, K., Nakamura, M., Matsui, T., Hara, T. J. (1988). Gustatory responses to tetrodoxin and saxitoxin in fish: a possible mechanism for avoiding marine toxins. Can. J. Fish. Aquat. Sci. 45: 2182-2186

Yazdandoust, M. H. (1985). Cancer crab larvae and goby fish: vector and victim of paralytic shellfish poisons (PSP). In: Anderson, D. M., White, A. W., Baden, D. G. (eds.) Toxic dinoflagellates. Elsevier, New York, p. 419-424

Manuscript first received: March 10, 1989

Revised version accepted: June 15, 1989 